\title{
Allergic Airway Inflammation
}

\author{
Gabriel Morán ${ }^{1}$, Claudio Henriquez² and Hugo Folch ${ }^{2}$ \\ ${ }^{1}$ Department of Pharmacology, Universidad Austral de Chile, \\ ${ }^{2}$ Department of Immunology, Universidad Austral de Chile, \\ Chile
}

\section{Introduction}

Allergic airway inflammation is one characteristic feature of asthma disease, with additional pathology including a reversible airway obstruction, airway hyperresponsiveness (AHR), infiltration of eosinophils and T-helper type 2 (Th2) cells into the airway submucosa, mucus hypersecretion, and airway remodeling (Agrawal \& Shao 2010). Allergic airway diseases are inflammatory disorders in which aberrant immune regulation occurs and susceptible individuals mount allergen specific responses. Inflammatory cells are recruited to the asthmatic airways or are activated in situ. The inflammatory cells include mast cells, macrophages, eosinophils, T lymphocytes, dendritic cells, basophils, neutrophils, and platelets (Barnes et al. 1998). Structural cells may also be important sources of inflammatory mediators in asthma. Airway epithelial cells, smooth muscle cells, endothelial cells, and fibroblasts are all capable of synthesizing and releasing inflammatory mediators (Levine, 1995; Saunders et al. 1997; John et al. 1997). Moreover, these cells may become the major source of inflammatory mediators in the airway, which may explain how asthmatic inflammation persists even in the absence of activating stimuli. A majority of patients with asthma have an atopic, allergic background (Robinson 2000). The prevailing consensus in regards to these patients is that the immunological basis of atopic sensitization and allergic disease results from inappropriate Th2 cell responses to common environmental proteins termed allergens (Robinson 2009).

Here, we summarize recent findings regarding how immune response and inflammatory cells contribute to allergic airway inflammation and discuss recent progress in the regulation of these cells.

\section{Immune mechanism}

In general, airway inflammation involves the activation of pathogenic-specific inflammatory cells, modulation of transcription factors and release of inflammatory mediators (Barnes et al. 1998). Allergic asthma, classified as a type 1 hypersensitivity reaction, involves allergenspecific immunoglobulins of the IgE class bound to high-affinity Fce receptors (FceR) on the surface of basophils and mast cells present in the subepithelial layer of the airways. Crosslinking of the receptor initiates a coordinated sequence of biochemical and morphological events that results in exocytosis (figure 1) of secretory granules containing histamine or other pre-formed inflammatory mediators; synthesis and secretion of newly formed lipid mediators, such as prostaglandins and leukotrienes; and synthesis and secretion of 
cytokines (Will-Karp et al. 1999). Many mediators are released in asthma, and it is clear that these mediators interact with each other in some way. Mediators may act synergistically to enhance each other's effects, or one mediator may modify the release or action of another mediator. Although the involved signaling pathways have been extensively studied, the precise sequence of events is still not well understood (Turner et al. 1999; Kim et al. 1997; Ali., et al. 2001; Ching et al., 2001; Siraganian 2003; Galli et al. 2008; Kim et al. 2008; Saini et al. 2009; Moran et al. 2010a,b; Colgan \& Hankel 2010). The inflammatory mediators are capable of contracting airway smooth muscle cells, inducing edema and mucus secretion, which leads to narrowed, constricted airways. Furthermore, locally produced chemokines stimulate the recruitment of eosinophils, macrophages, neutrophils, and $\mathrm{T}$ lymphocytes (Broide 2001).

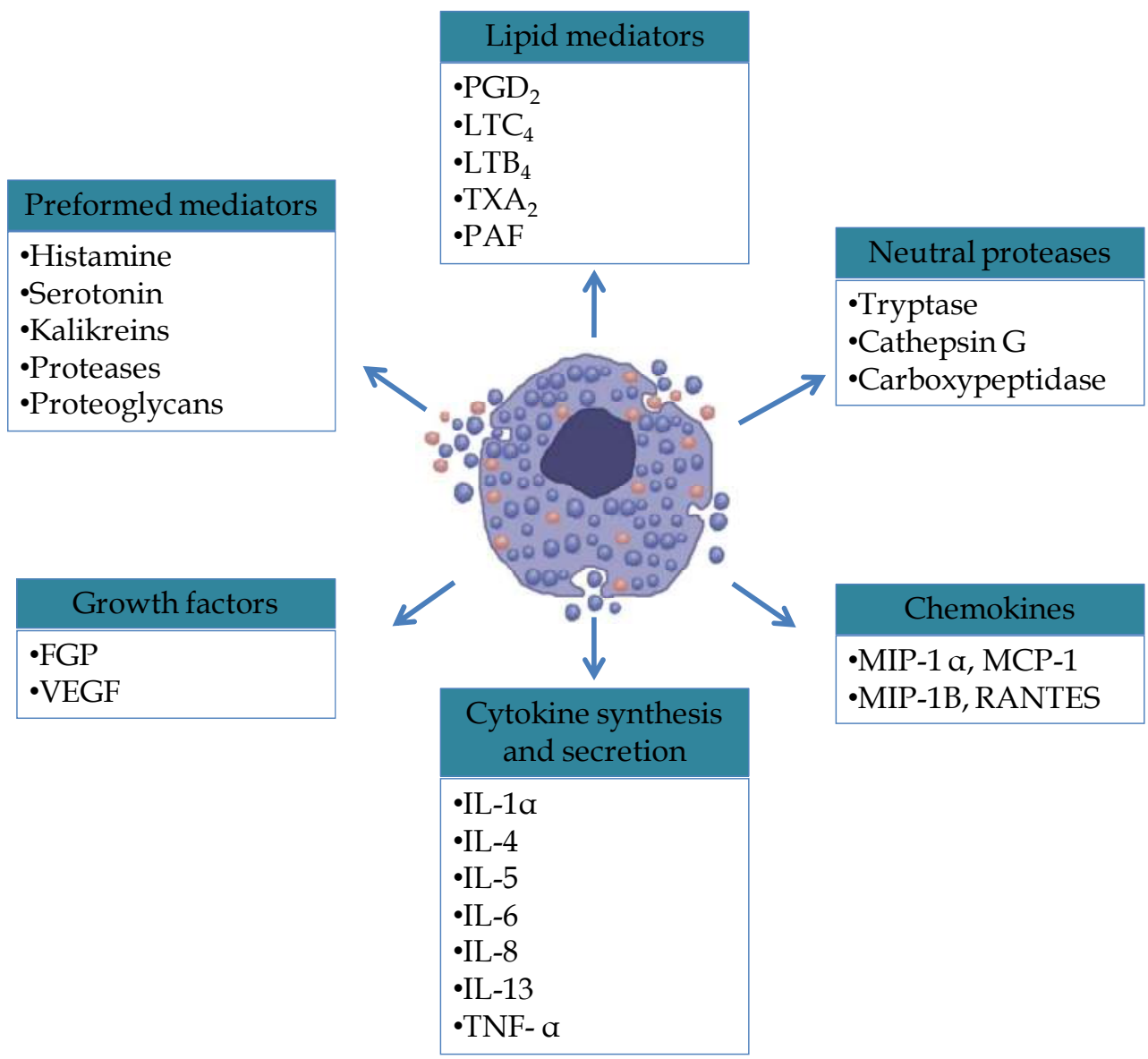

Fig. 1. Products of Mast Cells. PGD2, prostaglandin D2; LTC4, leukotriene C4; PAF, plateletactivating factor; FGP, fibroblast growth factor; VEGF, vascular endothelial growth factor, MIP; macrophage inflammatory protein; RANTES, regulated on activation, normal T-cell expressed and secreted MCP-1, monocyte chemotactic protein-1. 


\subsection{Role of $T$ cells in airways allergy disease}

$\mathrm{T}$ cells play an important role in the modulation of the immune response and are critical during allergy airway pathogenesis. Since 1986, the Th1/Th2 paradigm has dominated the understanding of the pathophysiology of asthma and allergic disease (Akbari et al. 2003). It is generally accepted that allergic respiratory disease in adults is associated with active Tcell immune responses to inhaled allergens that are skewed toward the Th2 phenotype, which is in contrast to a Th1-skewed immunity in healthy individuals (Agrawal and Shao 2010). Experimental animals model have been useful in the immunological delineation of the role of $\mathrm{T}$ cells and $\mathrm{T}$ cell-derived cytokines in the pathogenesis of airway allergy disease. In these animal models, sensitization with various allergens, such as ovalbumin, house dust mite, and aspergillus, induce a phenotype closely resembling that observed in human asthma (Hausding et al. 2008; Humar et al. 2008; Allen 2009; Bates et al. 2009; Qarcoo et al. 2009; Moran \& Folch 2011).

Th2-associated cytokines such as IL-4 are important in driving IgE production to allergens and are essential in the initiation of an allergic airway response (Coyle et al. 1995). IL-5 contributes to the development, recruitment and activation of eosinophils at the site of the Th2 inflammatory response, which characterizes allergic disease. IL-9 is an important regulator of mast-cell activation. Studies suggest that IL-13 has an important role in the effector phase of the allergy response, specifically airway inflammation, bronchial hyperresponsiveness and mucus cell hypersecretion (Wills-Karps et al. 1998; Wills-Karps et al. 1999 ). The involvement of each the specific Th2 cytokines in atopic airway response has been demonstrated in studies in which IL-4, IL-5, IL-9 and IL-13 have been manipulated through either antibody blockade (Kung et al. 1995; Gavet et al. 1997) or gene targeting (Brusselle et al. 1995; Foster et al. 1996; Spergel et al. 1999). Additionally, IL-21 has been shown to be important in the development of Th2 immune response (Frohlich et al. 2007). Frohlich and colleagues (2007) suggest that although the mechanisms by which IL-21 regulates allergy inflammation are unknown, IL-21 may be important for Th2-cell survival or migration to peripheral tissues. On the other hand, Th1 cells are also pro-inflammatory, and the development of a Th1-associated inflammatory response can exacerbate asthma and allergic disease. IFN-Y is often present at sites of allergic inflammation and is thought to contribute to the disease. Th1 cells cross-regulate Th2 cells in some systems, and it was thought that Th1 cells downmodulated the effects of Th2 cells. However, recent advances in immunology have raised the possibility that other mechanisms may drive or co-exist with pathology in some patients with Th2-type allergy airway inflammation. New effector T-cell lineages have recently been identified. Th17 cells, which differentiate from naïve CD4+ T cells under the influence of IL-6/IL-21/IL-23 and transforming growth factor (TGF)- $\beta$ via the signal transducer and activator of transcription 3 (STAT3)-ROR үt pathway, are mainly responsible for neutrophilia in allergic severe asthma (Louten et al. 2009). Moreover, a variety of cytokines derived from epithelium, fibroblasts and other airway structural cells have recently been shown to have an important potential for interaction with Th1, Th2, Th17, eosinophil and mast cells. These cytokines include the following: proinflammatory cytokines [IL-1 $\beta$, IL-6, IL-11, tumor necrosis factor (TNF)- $\alpha$, and granulocyte/macrophage colony-stimulating factor (GMCSF)], which are involved in innate host defense; antiinflammatory cytokines [IL-10, IFN- $\gamma$, IL-12, and IL-18]; growth factors [platelet derived growth factor (PDGF), TGF- $\beta$, fibroblast growth factor (FGF), and epidermal growth factor (EGF)]; and chemotactic cytokines or chemokines [RANTES, monocyte chemoattractant protein (MCP)-1-MCP-5, eotaxin, and IL-8] (Hamid and Tulic 2009). 
Conversely, investigations into the contribution of cytotoxic CD8+ T cells towards the development of allergic airway inflammation are not well understood. The depletion of CD8+ T cells does not affect airway response to allergen challenge in mice (Gonzalo et al. 1996). However, a subset of CD $8+T$ cells, named Tc2 cells, can produce Th2 cytokines such as IL-4, IL-5, and IL-13, which are increased in the bronchoalveolar lavage fluids (BALF) of allergic asthmatic patients in studies. This rise of cytokine production suggests that the immune responses to virus infections are characterized by an increase in the frequency of type 2 cytokine-producing T cells when they take place in an allergic environment in animal models (Coyle et al. 1995; Makela et al. 2003). Human studies show that CD8+ T cells from both normal and asthmatic subjects have the capacity to produce type 2 cytokines (Stanciu et al. 1996; Stanciu et al. 1997). In addition, the stimulation of CD8+ T cells from normal, healthy subjects in an IL-4 rich milieu significantly increased the number of IL-5-positive CD8+ T cells (Stanciu et al. 2001). Additionally, studies suggest that during a respiratory virus infection activated CD8+ T cells from asthmatic subjects may produce excess type 2 cytokines and may contribute to asthma exacerbation by augmenting allergic inflammation (Stanciu et al. 2005). These studies thus demonstrate that the frequency of airway CD8+ T cells producing type 2 cytokines are as great as those of airway CD4+ T cells are and that both are increased in asthma and are related to disease severity (Cho et al. 2005).

\subsubsection{Transcription factors responsible for the Th1/Th2/Th17 cells and inflammatory mediators}

Transcription factors are DNA-binding proteins that regulate the expression of inflammatory genes, including enzymes involved in the synthesis of inflammatory mediators as well as protein and peptide mediators (Barnes et al. 1998). Inflammation associated with hypersensitivity results from an exaggerated expression of inflammatory genes, and a number of researchers have explored the mechanisms implicated in inflammatory gene induction (Barnes and Karin, 1997; Barnes and Adcock, 1998). Many transcription factors are cell-specific and are crucial in cell differentiation and the regulation of specific cellular processes such as proliferation, enzymes, and cytokine expression. In animal models of airway diseases, such as atopic asthma, nuclear factor NF-(kB), activator protein-1 (AP-1), GATA-3, JunB and c-Maf play a central role in the control of airway inflammation (Finotto et al. 2001; Nguyen et al. 2003; Yamashita et al. 2007). In humans, there is evidence that NF-kB, AP-1 and GATA-3 expression is increased in asthmatic airways (Hart et al., 1998; Taha et al. 2003). Furthermore, these transcription factors are key downstream regulators of Th1/Th2/Th17 cytokine function and are phosphorylated/dephosphorylated in the asthmatic airway (Pernis and Rothman, 2002). The Th1 master regulator, T-box transcription factor (T-bet), is extensively expressed in polarized Th1 cells, and its expression and activity are induced by IL-12 via STAT4 or by IFN- $\gamma$ via STAT1. IL-4 drives differentiation of IL-4-producing Th2 cells through STAT6, which is necessary and sufficient for the induction of the Th2 master regulator, GATA-3. Moreover, transcription factor c-Maf is selectively expressed in Th2 cells as a downstream effector of the IL-4/IL-4R/STAT6 signal transduction pathway, primarily regulating IL-4 expression in Th2 cells (Agrawal \& Shao 2010).

\subsubsection{Role of regulatory $\mathrm{T}$ cells in allergy airway diseases}

As mentioned previously, allergic airway diseases show complex genetic associations and have a hereditary component (Cookson \& Moffat 2004). However, the rapid and 
geographically localized nature of the increase in the incidence of allergic diseases indicates compounding effects of recent changes in environment and lifestyle in the Western world. How these factors impact disease by promoting immune responses to allergens is a subject of considerable debate, which has led to the "hygiene hypothesis" (Wills-Karp et al. 2001; Liu \& Murphy 2003). According to the theory, in its simplest iteration, the increase in hygienic living conditions and in the use of antibiotic and sterile food preparations resulted in the separation of the immune system from positive microbial exposure early in life (Martinez and Holt, 1999). The immunoregulatory mechanisms remain underdeveloped, and an imbalance in immune homeostasis predisposes to the development of $\mathrm{T}$ helper type 2-biased immune responses and, consequently, allergic disease (Feleszko et al. 2005).

Recent studies indicate that Th2 responses that are characteristic of allergic manifestations can be regulated by naturally occurring CD4+CD25+ regulatory $\mathrm{T}$ (nTreg) cells. These cells are a functionally mature T-cell subpopulation, which play key roles in the maintenance of immunologic self-tolerance and negative control of a variety of physiological and pathological immune responses (Sakagushi et al. 2006). They also constitutively express transcription factor forkhead box P3 (FoxP3), which prevents the deviation of Tregs into effector T cells (Burchill et al. 2007). These cells originate in the thymus, but inducible Treg (iTreg) cells, which have similar properties and characteristics, can also be induced in the periphery. Regulatory $\mathrm{T}$ cells appear to control the development of autoimmune disease and transplant rejection and may play a critical role in controlling asthma and allergy (Akdis et al. 2005). Several studies indicate that the function of naturally occurring Treg cells is impaired or altered in patients with allergies compared with normal healthy individuals. The adoptive transfer of antigen-specific CD4+CD25+ T-regs attenuates acute allergic airway inflammation, AHR, and airway remodeling. The capacity of Treg cells to inhibit the proliferation of naive $\mathrm{T}$ cells in vitro requires cell-cell contact (induction of an inhibitory signals on CD4+ and CD8+ T cells); however, in vivo, these cells can also function through induction of inhibitory cytokines (such as TGF- $\beta$ and IL-10) and inhibition of antigenpresenting capacity (Zheng et al. 2006; Kearly et al. 2008). These data suggest that one potential treatment option would be to enhance CD4+CD25+ Tregs in addition to targeting decreased Th2 populations. An example of this therapeutic strategy would be allergen desensitization immunotherapy, which has been in use for almost a century and is one of the few specific immunomodulatory treatments that are commonly used for allergic asthma (Akbari et al. 2003; Kearly et al. 2008). Understanding the immune mechanisms that underlie successful allergen immunotherapy offers the potential to improve current allergenimmunotherapy regimens. Some authors suggest that this therapy might function, at least in part, to promote the generation of IL-10 and TGF- $\beta$-secreting regulatory $\mathrm{T}$ cells (Hawrylowicz \& Garra 2005; Shevach et al. 2008).

\section{Apoptosis regulation in allergy airway disease}

Apoptosis is defined as a genetic program that eliminates unneeded, senescent, or damaged cells (Thompson 1995). Moreover, apoptosis is an important regulatory mechanism in the selection and containment of an immunocompetent $\mathrm{T}$ cell population, in $\mathrm{T}$ cell development and during immune responses. Dysregulation of apoptosis has been implicated in a range of diseases including tumors, neurodegenerative disorders, autoimmunity (Cohen 1999) and, perhaps, allergic asthma (Vignola et al. 1999; Woolley et al. 1996). Studies in human patients have demonstrated that reduced $T$ cell apoptosis plays an important role in the pathogenesis 
of allergic bronchial asthma (Cormican et al. 2001; Vignola et al. 1999; De Rose et al. 2004). These findings are also consistent in murine models of asthma (Jayaraman et al. 1999; Tong et al. 2006; Finotto et al. 2007). In addition, increasing lines of evidence suggest that changes in programmed cell death mechanisms in both mobile and resident cells of the airway may directly contribute to the development and clinical severity of allergy airway inflammation (Vignola et al. 2000).

Apoptosis has emerged as a major mechanism in the clearance of activated $\mathrm{T}$ cells during the resolution of an inflammatory response (Akbar and Salmon 1997). Inadequate T cell apoptosis in asthma patients appears to interfere with normal $\mathrm{T}$ cell elimination, resulting in $\mathrm{T}$ cell accumulation, which contributes to chronic inflammation and may be the major underlying cause for tissue damage, remodeling and repair (Müller et al. 2006; Vignola et al. 2000). Spinozzi et al. (1998) reported that pulmonary T cells isolated from the BALF of atopic asthma patients showed hypoexpression of Fas and FasL; this result may explain the low frequency of apoptosis in this group of patients. In contrast, horses with acute airway allergy have increased apoptosis of airway lymphocytes, which may partially explain the rapid resolution of the pathology once the allergen is removed in this allergy model (Moran et al. 2011). However, these authors suggest additional studies to examine apoptosis and cytokine profiles in other stages of the disease. In addition, basal levels of apoptotic activity were significantly lower in BALF lymphocytes from asthmatic subjects compared with peripheral blood lymphocytes from the same subjects. These data indicate that airway inflammation in asthma is associated with a reduced susceptibility to apoptosis, which may lead to enhanced survival of lymphocytes in the bronchial mucosa and prolonged inflammation (Müller et al. 2006). Other molecules are involved in the programmed cell death process, including members of the Bcl-2 gene family, which are known to inhibit apoptosis. Studies have shown that Bcl-2 expression is increased in lymphoid cells obtained from the airways of asthmatic patients and that neutralization of IL-10, an important inducer of $\mathrm{Bcl}-2$, decreases $\mathrm{Bcl}-2$ expression and apoptosis of cells from the respiratory tract of asthmatic patients (Hamzaoui et al. 1999a; Hamzaoui et al. 1999b).

\section{Airway remodeling}

Recently, airway remodeling has become a field of special interest in chronic asthma, chronic bronchitis, chronic obstructive pulmonary disease (COPD) and cystic fibrosis research as the process that causes patients to become largely resistant to medication and is an important factor in the development of irreversible airflow limitation (James et al., 1989; Lange et al., 1998; Jeffery et al., 2000; Kranenburg et al., 2002 Wegmann, 2008). In tissues from human with these diseases, remodeling changes include goblet cell and mucous gland hyperplasia, subepithelial fibrosis, neovascularization, airway smooth muscle (ASM) growth as well as increased deposition of extracellular matrix (ECM) proteins such as collagens, elastin, laminin, and proteoglycans around the smooth muscle and an overall thickening of the airway wall (Roche et al 1989; Laitinen et al., 1997; Davies et al., 2003). The molecular mechanisms that drive remodeling remain undefined, but many growth factors and cytokines, including fibroblast growth factor (FGF)-1, FGF-2, and transforming growth factor (TGF)- $\beta 1$, that are released from the airway wall have the potential to contribute to airway remodeling, revealed by enhanced ASM proliferation and increased ECM protein deposition (Parameswaran et al., 2006; Kariyawasam and Robinson 2007). TGF- $\beta 1$ is an important fibroblast chemotactic factor. Fibroblast numbers have been shown to correlate 
with TGF- $\beta 1$ expression. TGF- $\beta 1$ also induces the differentiation of fibroblasts to myofibroblasts (Postlethwaite and Seyer, 1995; Vignola et al., 1997; Thannickal et al., 2003). Morover, TGF- $\beta 1$ and FGF-1 stimulate mRNA expression of collagen I and III in ASM cells, suggesting their role in the deposition of extracellular matrix proteins by ASM cells in the airways of patients with chronic lung diseases. Furthermore, ECM proteins promote the survival, proliferation, cytokine synthesis, migration, and contraction of human ASM cells contributing to airway wall remodeling (Parameswaran et al., 2006)

\section{Conclusion}

Asthma allergy disease is multifactorial, characterized by allergy airway inflammation and increased bronchoconstrictory response to nonspecific stimuli. The current body of knowledge suggests that the inflammatory component of asthma results from a combination of elements from both the innate and adaptive immune responses. Expression of cytokine patterns consistent with Th1, Th2 and Th17 cell activation has been identified and determined to vary based on the chronic condition of the disease. Activation of transcription factors plays a pivotal role in regulating cellular signaling pathways through dynamic modulation of cytokines, chemokines, and similar molecules. The regulation of the apoptosis of inflammatory cells, fibroblasts, and myocytes through Bcl-2 expression contributes to the establishment of chronic disease and remodeling. Tregs seem to play a pivotal role in balancing tolerance versus immunologic response to allergens. Therapy with immunomodulators that enhance tolerance to allergens and increase Tregs would be most effective in the treatment of allergy airway disease.

\section{Acknowledgment}

The author acknowledges the support of Fondecyt grants (Chilean governments), 11100196.

\section{References}

Agrawal, D.K \& Shao Z. (2010).Pathogenesis of allergic airway inflammation. Current Allergy and Asthma Reports 10, 39-4; ISSN 1529-7322

Ali, H; Maeyama, K; Sagi-Eisenberg, R \& Beaven, M.A. (2001). Antigen and thapsigargin promote influx of $\mathrm{Ca}^{2+}$ in rat basophilic $\mathrm{RBL}-2 \mathrm{H} 3$ cells by ostensibly similar mechanisms that allow filling of inositol 1,4,5-triphosphate-sensitive and mitochondrial $\mathrm{Ca}^{2+}$ stores. The Biochemical journal 304, 431-440; ISSN 0264-6021

Allen, I.C. (2009). Searching for an improved mouse model of allergic airway disease using dual allergen exposures. Disease Models \& Mechanism. 12, 519-520; ISSN 1754-8403

Akbar, A.N \& Salmon, M. (1997). Cellular environments and apoptosis: tissuemicroenvironments control activated T cell death. Immunology Today 18, 7266; ISSN 0167-5699

Akbari, O; Stock, P; DeKruyff, R.H \& Umetsu DT.(2003). Role of regulatory T cells in allergy and asthma. Current Opinion in Immunology 15, 627-633; ISSN 0952-7915 
Akdis, M; Blaser, K \& Akdis C.A (2005). T regulatory cells in allergy: novel concepts in the pathogenesis, prevention, and treatment of allergic diseases. The Journal of Allergy Clinical Immunology 116, 961-968; ISSN 0091-6749

Barnes, PJ; Fan, K \& Chung, C. (1998). Inflammatory mediators of asthma: An Update. Pharmacological Reviews 50, 515-596; 0031-6997

Barnes, P.J \& Adcock, I.M (1998). Transcription factors and asthma. The European Respiratory Journal 2, 221-234; ISSN 0903-1936

Barnes, P.J \& Karin, M. (1997). Nuclear factor-kB: A pivotal transcription factor in chronic inflammatory diseases. The New England Journal Medicine 336,1066-1071; ISSN 0028-4793

Bates, J.H; Rincon, M \& Irvin C.G. (2009). Animal models of asthma. American Journal of Physiology. Lung and Cellular and Molecular Physiology 297, L401-1; ISSN 10400605

Broide D.H. (2001). Molecular and cellular mechanisms of allergic disease. The Journal of Allergy Clinical Immunology 108, S65-S71; ISSN 0091-6749

Brusselle, G; Kips, J; Joos, G; Bluethmann, H \& Pauwels R (1995). Allergen-induced airway inflammation and bronchial responsiveness in wild-type and interleukin- 4deficient mice. American Journal of Respiratory Cell and Molecular Biology 12, 254-259; ISSN 1044-1549

Burchill, M.A; Yang, J; Vogtenhuber, C; Blazar B.R \& Farrar, M.A. (2007). IL-2 receptor betadependentSTAT5 activation is required for the development of Foxp3+ regulatory T cells. The Journal of Immunology 178, 280-290; ISSN 0022-1767

Cohen J.J. (1999). Apoptosis: mechanisms of life and death in the immune system. The Journal of Allergy and Clinical Immunology 103, 548-54; ISSN 0091-6749

Ching T.T; Hsu, AL; Johnson A.J \& Chen C.S. (2001). Phosphoinositide 3-kinase facilitates antigen-stimulated $\mathrm{Ca}(2+)$ influx in RBL-2H3 mast cells via a phosphatidylinositol 3,4,5-trisphosphate-sensitive $\mathrm{Ca}(2+)$ entry mechanism. The Journal of Biological Chemistry 276, 14814-14820; ISSN 0021-1767

Cho, S.H; Stanciu, L.A; Holgate, S.T \& Johnston SL (2005). Increased interleukin-4, interleukin-5, and interferon-gamma in airway CD4+ and CD8+ T cells in atopic asthma. American Journal of Respiratory Critical and Care Medicine 171:224-230; ISSN 1073-449X

Colgan JD, Hankel IL. (2010). Signaling pathways critical for allergic airway inflammation. Current in Opinion and Allergy Clinical Immunology 10, 42-47; ISSN 1528-4050

Cormican, L; O'Sullivan S; Burke, C.M \& Poulter, L.W. (2001). IFNgamma but not IL-4 T cells of the asthmatic bronchial wall show increased incidence of apoptosis. Clinical and Experimental Allergy 31, 731-739; ISSN 0954-7894

Cookson, W \& Moffatt M. (2004). Making sense of asthma genes. The New England Journal of Medicine 51, 1794-6; ISSN 0028-4793

Coyle, A.J; Erard, F; Bertrand, C; Walti, S; Pircher, H \& Le Gros G. (1995). Virusspecific CD8+ cells can switch to interleukin 5 production and induce airway eosinophilia. The Journal of Experimental Medicine, 181,1229-1233; ISSN 022-1007

Davies, D.E; Wicks, J; Powell, R.M; Puddicombe, S.M \& Holgate ST. (2003). Airway remodeling in asthma: new insights. The Journal of Allergy and Clinical Immunology 111, 215-25; ISSN 0091-6749 
De Rose, V; Cappello, P; Sorbello, V; Ceccarini, B; Gani, F; Bosticardo, M; Fassio, S \& Novelli, F. (2004). IFN-gamma inhibits the proliferation of allergen-activated T lymphocytes from atopic, asthmatic patients by inducing Fas/FasL-mediated apoptosis. Journal of Leukocyte Biology 76, 423-32; ISSN 0741-5400

Feleszko, W; Jaworska, J \& Hamelmann, E. (2006). Toll-like receptors-novel targets in allergic airway disease (probiotics, friends and relatives). European Journal of Pharmacology 533, 308-318; ISSN 0014-2999

Finotto, S; De Sanctis, G; Lehr, H; Herz, U; Buerke, M; Schipp, M; Bartsch, B; Atreya, R; Schmitt, E; Galle, P; Renz, H \& Neurath M. (2001). Treatment of allergic airway inflammation and hyperresponsiveness by antisense-induced local blockade of GATA-3 expression. Journal of Experimental Medicine 193, 1247-1260; ISSN 0221007

Finotto, S; Eigenbrod, T; Karwot, R; Boross, I; Doganci, A; Ito, H; Nishimoto, N; Yoshizaki, K; Kishimoto, T; Rose-John, S; Galle, P.R \& Neurath, M.F. (2007). Local blockade of IL-6R signaling induces lung CD4+ T cell apoptosis in a murine model of asthma via regulatory T cells. International Immunology 19, 685-93; ISSN 0953-8178

Foster, P.S; Hogan, S.P; Ramsay, A.J; Matthaei, K.I \& Young IG (1996). Interleukin 5 deficiency abolishes eosinophilia, airways hyperreactivity, and lung damage in a mouse asthma models. The Journal of Experimental Medicine 183, 195-201; ISSN 0221007

Fröhlich, A; Marsland, B.J; Sonderegger, I; Kurrer, M; Hodge, MR; Harris, N.L \& Kopf M. (2007). IL-21 receptor signaling is integral to the development of Th2 effector responses in vivo.Blood 109, 2023-2031; ISSN 0006-4971

Galli, S.J; Grimbaldeston, M \& Tsai M. (2008). Immunomodulatory mast cells: negative, as well as positive, regulators of immunity. Nature Review Immunology 8, 478-486; ISSN 1474-1733

Gonzalo JA, Lloyd CM, Kremer L, Finger E, Martinez-A C, Siegelman MH, Cybulsky M,

Gutierrez-Ramos JC (1996). Eosinophil recruitment to the lung in a murine model of allergic inflammation. The role of T cells, chemokines, and adhesion receptors. The Journal of Clinical Investigation 98, 2332-2345; ISSN 0021-9738

Gavett, SH; O’Hearn, D.J; Karp, C.L Patel EA, Schofield, B.H; Finkelman F.D \& Wills-Karps M (1997). Interleukin-4 receptor blockade prevents airway responses induced by antigen challenge in mice. American Journal of Physiology 272, L253-L261; ISSN 00029513

Hamid, Q \& Tulic M. (2009). Immunobiology of asthma. Annual Review Physiology 71, 489507; ISSN 0066-4278

Hamzaoui, A; Hamzaoui, K; Salah, H \& Chabbou, A. (1999a). Lymphocytes apoptosis in patients with acute exacerbation of asthma. Mediators of Inflammation 8, 237-243; ISSN 0962-9351

Hamzaoui, K; Hamzaoui, A.; Zakraoui, L \& Chabbou, A. (1999b). Expression of Bcl-2 in inflammatory sites from patients with active Behçet's disease. Mediators of Inflammation 8, 101-106; ISNN 0962-9351

Hart, L; Krishman, V; Adcock, I; Barnes, P \& Chung K. (1998). Activation and localization of transcription factor, nuclear factor-kappaB, in asthma. American Journal of Respiratory and Critical Care Medicine 158, 1585-1592; ISSN 1073-449X 
Hausding, M; Sauer, K; Maxeiner, J.H \& Finotto S. (2008) Transgenic models in allergic responses. Current Drug Targets 9, 503-10; ISSN 1389-4501

Hawrylowicz, C.M \& O'Garra A (2005). Potential role of interleukin-10-secreting regulatory T cells in allergy and asthma. Nature Reviews Immunology 5, 271-283; 1474-1733

James, AL; Pare, PD \& Hogg JC. (1989). The mechanics of airway narrowing in asthma. The American Review of Respiratory Disease 139, 242 246; ISSN 0003-0805

Jayaraman, S; Castro, M; O'Sullivan, M; Bragdon, M.J \& Holtzman, M.J. (1999) Resistance to Fas-mediated $\mathrm{T}$ cell apoptosis in asthma. The Journal of Immunology 162, 1717-22; ISSN 0022-1767

Jeffery, PK; Laitinen, A \& Venge P. (2000). Biopsy markers of airway inflammation and remodelling. Respiratory Medicine 94, S9-S15; ISSN 0954-6111

John, M; Hirst, S.J; Jose, P; Robichaud, A; Witt, C; Twort, C; Berkman, N; Barnes, P.J \& Chung KF. (1997). Human airway smooth muscle cells express and release RANTES in response to Th1 cytokines: Regulation by Th2 cytokines. The Journal of Immunology 158:1841-1847; ISSN 0022-1767

Kariyawasam; H.H \& Robinson D.S. (2007). The role of eosinophils in airway tissue remodelling in asthma. Current Opinion in Immunology 19, 681-686; ISSN 09527915

Kearley, J; Robinson, D.S \& Lloyd C.M. (2008). CD4+CD25+ regulatory T cells reverse established allergic airway inflammation and prevent airway remodeling. Journal of Allergy Clinical Immunology 122, 617-624; ISSN 0091-6749

Kim, T.D; Eddlestone, G.T; Mahmoud, S.F; Kuchtey, J \& Fewtrell C. (1997). Correlating Ca2+ responses and secretion in individual RBL-2H3 mucosal mast cells. The Journal of Biological Chemestry 272, 31225-31229; ISSN 0021-9258

Kim, M.S; Radinger, M \& Gilfillan AM. (2008). The multiple roles of phosphoinositide 3kinase in mast cell biology. Trends in Immunology 29, 493-501; ISSN 1471-4906

Kranenburg, A. R., Willems-Widyastuti, A., Saxena, P. R., Sterk, P. J., de Boer, W. I. \& Sharma, H. S. (2002). Enhanced pulmonary expression of extracellular matrix proteins in central airways of COPD patients. American Journal of Respiratory Critical and Care Medicine 165, A600; ISNN 1073-449X

Kung, T.T; Stelts, D.M; Zurcher, J.A; Adams, G.K 3rd; Egan, R.W; Kreutner, W; Watnick, A.S; Jones, H \& Chapman R.W (1995). Involvement of IL-5 in a murine model of allergic pulmonary inflammation: prophylactic and therapeutic effect of an anti-IL5 antibody.. American Journal of Respiratory and Cell Molecular Biology. 13, 360-365; ISSN 1044-1549

Kumar, R.K; Herbert, C \& Foster PS. (2008). The "classical" ovalbumin challenge model of asthma in mice. Current Drug Targets 9, 485-94; ISSN 1389-4501

Lang, P; Parner, J; Vestbo, J; Schnohr, P \& Jensen G. (1998). A 15-year followup study of ventilatory function in adults with asthma. The New England Journal of Medicine 339, 1194-1200; ISSN 0028-4793

Laitinen, A., Altraja, A., Kampe, M., Linden, M., Virtanen, I. \& Laitinen, L. A. (1997) Tenascin is increased in airwaybasement membrane of asthmatics and decreased by an inhaled steroid. American Journal of Respiratory Critical and Care Medicine 156, 951-958; ISSN 1073-449X 
Levine, S.J (1995). Bronchial epithelial cell-cytokine interactions in airway epithelium. Journal of Investigative Medicine 43, 241-249; 1081-5589

Liu, A.H \& Murphy J.R (2003). Hygiene hypothesis: fact or fiction?Journal of Allergy Clinical Immunology 111, 471-8; ISSN 0091-6749

Louten, J; Boniface, K \& de Waal Malefyt R. (2009). Development and function of Th17 cells in health and disease. Journal of Allergy Clinical Immunology 123, 1004-1011; ISSN 0091-6749

Martinez, F.D \& Holt PG. (1999). Role of microbial burden in aetiology of allergy and asthma..Lancet 354, SII12-5; ISSN 0140-6736

Makela, M.J; Tripp, R; Dakhama, A; Park, J.W; Ikemura, T; Joetham, A; Waris, M; Anderson, L.J \& Gelfand EW. (2003). Prior airway exposure to allergen increases virusinduced airway hyperresponsiveness. Journal of Allergy Clinical Immunology 112, 861-869 ; ISSN 0091-6749

Morán, G; Burgos, R; Araya, O \& Folch H. (2010a). In vitro bioassay to detect reaginic antibodies from the serum of horses affected with Recurrent Airway Obstruction. Veterinary Research Communications 34, 91-99; ISSN 0165-7380

Morán, G; Folch, H; Burgos, R; Araya, O \& Barria M. (2010b): Detection of reaginic antibodies against Faenia rectivirgula from the serum of horses affected with Recurrent Airway Obstruction by an in vitro bioassay. Veterinary Research Communications 34, 719-726; ISSN 0165-7380

Morán, G \& Folch H. 2011. Recurrent airway obstruction in horses - an allergic inflammation: a review. Veterinarni Medicina 56, 1-13; ISSN 0375-8427

Moran, G; Buechner-Maxwell, V.A; Folch, H; Henriquez, C; Galecio, J.S; Perez, B; Carrasco, C \& Barria (2011). Increased apoptosis of CD4 and CD8 T lymphocytes in the airways of horses with recurrent airway obstruction..Veterinary Research Communications 35, 447-456; ISSN 0165-7380

Müller, M; Grunewald, J; Olgart Höglund, C; Dahlén, B; Eklund, A \& Stridh, H. 2006 Altered apoptosis in bronchoalveolar lavage lymphocytes after allergen exposure of atopic asthmatic subjects. The European Respiratory Journal 28, 513-22; ISSN 0903 1936

Nguyen, C; Teo, J.L; Matsuda, A; Eguchi, M; Chi, E; Henderson, Jr W \& Kahn M. (2003). Chemogenomic identification of Ref-1/AP-1 as a therapeutic target for asthma. Proceedings of the National Academy of Sciences of the United States of America 100, 1169-1173; ISSN 0027-8424

Parameswaran, K; Willems-Widyastuti, A; Alagappan, VK; Radford, K; Kranenburg, A.R. \& Sharma HS. (2006). Role of extracellular matrix and its regulators in human airway smooth muscle biology. Cell Biochemistry and Biophysics 44, 139-146; ISSN 10859195

Pernis, A.B \& Rothman PB. (2002). JAK-STAT signaling in asthma. The Journal of Clinical Investigation 109, 1279-1283; ISSN 0021-9738

Postlethwaite, AE \& Seyer JM. (1995). Identification of a chemotactic epitope in human transforming growth factor-beta 1 spanning amino acid residues 368-374. Journal of Cellular Physiology 164, 587-592; ISSN 0021-954 
Quarcoo, D; Pavlovic, S \& Joachim RA. (2009). Stress and airway reactivity in a murine model of allergic airway inflammation. Neuroimmunomodulation. 16, 318-24; ISSN 1021-7401

Robinson, D. S. (2000). TH2 cytokines in allergic disease. British Medical Bulletin 56, 956-968; ISNN 0007-1420

Robinson D.S. (2010). Regulatory T cells and asthma. Clinical and Experimental of Allergy 39, 1314-1323; ISSN 0954-7894

Roche, W. R., Beasley, R., Williams, J. H. \& Holgate, S. T.(1989) Subepithelial fibrosis in the bronchi of asthmatics. Lancet 1, 520-524; ISSN 0140-6736

Sakaguchi, S; Ono, M; Setoguchi, R; Yagi, H; Hori, S; Fehervari, Z; Shimizu, J; Takahashi, T \& Nomura T. (2006). Foxp3+ CD25+ CD4+ natural regulatory T cells in dominant self-tolerance and autoimmune disease. Immunological Reviews 212, 8-27; ISSN 01052896

Saini, S.S; Paterniti, M; Vasagar, K; Gibbons, S.P; Jr Sterba, P.M \& Vonakis BM. (2009). Cultured peripheral blood mast cells from chronic idiopathic urticaria patients spontaneously degranulate upon IgE sensitization: Relationship to expression of Syk and SHIP-2. Clinical Immunology 132, 342-348; ISSN 1521-6616

Saunders, M.A; Mitchell, J.A; Seldon, P.M; Barnes, P.J; Giembycz, M.A \& Belvisi MG. (1997). Release of granulocyte-macrophage colony-stimulating factor by human cultured airway smooth muscle cells: Suppression by dexamethasone. British Journal of Pharmacology 120, 545-546; ISSN 0007-1188

Shevach, E.M; Tran, D.Q; Davidson, T.S \& Andersson J. (2008). The critical contribution of TGF-beta to the induction of Foxp3 expression and regulatory $\mathrm{T}$ cell function. European Journal of Immunology 38, 915-917; ISSN 0022-1767

Siraganian RP. (2003). Mast cell signal transduction from the high-affinity IgE receptor.Current Opinion in Immunology 15, 639-46; ISSN 0952-7915

Spergel, J.M; Mizoguchi, E; Oettgen, H; Bhan, AK \& Geha RS. (1999).Roles of TH1 and TH2 cytokines in a murine model of allergic dermatitis. The Journal of Clinical Investigation 103, 1103-11; ISSN 0021-9738

Spinozzi, F; Fizzotti, M; Agea, E; Piattoni, S; Droetto, S; Russano, A; Forenza, N; Bassotti, G; Grignani, F \& Bertotto A. (1998). Defective expression of Fas messenger RNA and FAS receptor on pulmonary T cells from patients with asthma. Annals of Internal Medicine 128, 363-9; ISSN 0003-4819

Stanciu, L.A; Shute, J; Holgate, S.T \& Djukanovic R. (1996). Production of IL-8 and IL-4 by positively and negatively selected CD4+ and CD8+ human T cells following a fourstep cell separation method including magnetic cell sorting (MACS). Journal of Immunological Methods 189, 107-115; ISSN 0022-1759

Stanciu, L.A; Shute, J; Promwong, C; Holgate, S.T \& Djukanovic R. (1997). Increased levels of IL-4 in CD8+ T cells in atopic asthma. Journal of Allergy Clinical Immunology 100,373378; ISSN 0091-6749

Stanciu, L.A; Roberts, K; Lau, L.C.K; Coyle, A.J \& Johnston SL. (2001). Induction of type 2 activity in adult human CD8 Tcells by repeated stimulation an IL-4. International Immunology 13, 341-348; ISSN 0953-8178 
Stanciu, L.A; Roberts, K; Papadopoulos, N.G; Cho, S.H; Holgate, S.T; Coyle, A.J \& Johnston SL. (2005). IL-4 increases type 2, but not type 1, cytokine production in CD8+ T cells from mild atopic asthmatics. Respiratory Research 7; 6: 67; ISSN 1465-9921

Taha, R; Hamid, Q; Cameron, L \& Olivenstein R. (2003). T helper type 2 cytokine receptors and associated transcription factors GATA-3, c-MAF, and signal transducer and activator of transcription factor- 6 in induced sputum of atopic asthmatic patients. Chest 123, 2074-2082; ISSN 0012-3692

Thannickal, V.J; Lee, D.Y; White, E.S; Cui, Z; Larios, J.M; Chacon, R; Horowitz, J.C; Day, R.M \& Thomas PE. (2003). Myofibroblast differentiation by transforming growth factorbeta1 is dependent on cell adhesion and integrin signaling via focal adhesion kinase. The Journal of Biological Chemestry 278, 12384-12389; ISSN 0021-9258

Thompson, C.B. (1995). Apoptosis in the pathogenesis and treatment of disease. Science 267, 1456-1462; ISSN 0036-8075

Tong, J; Bandulwala, H.S; Clay, B.S; Anders, R.A; Shilling, R.A; Balachandran, D.D; Chen, B; Weinstock, J.V; Solway, J; Hamann, K.J \& Sperling, A.I. (2006) Fas-positive T cells regulate the resolution of airway inflammation in a murine model of asthma. The Journal of Experimental Medicine 203, 1173-84; ISSN 022-1007

Turner, H \& Kinet J.P. (1999) Signalling through the high-affinity IgE receptor Fc epsilonRI.. Nature 402, B24-30; ISSN 0028-0836

Vignola, A.M; Chanez, P; Chiappara, G; Merendino, A; Pace, E; Rizzo, A; la Rocca, A.M; Bellia, V; Bonsignore, G \& Bousquet J. (1997). Transforming growth factor-beta expression in mucosal biopsies in asthma and chronic bronchitis. American Journal of Respiratory and Critical Care Medicine 156, 591-599; ISSN 1044-1549

Vignola, A.M; Chanez, P; Chiappara, G; Siena, L; Merendino, A; Reina, C; Gagliardo, R; Profita, M; Bousquet, J \& Bonsignore, G. 1999 Evaluation of apoptosis of eosinophils, macrophages, and $\mathrm{T}$ lymphocytes in mucosal biopsy specimens of patients with asthma and chronic bronchitis. The Journal of Allergy Clinical Immunololy. 103, 563-573; ISSN 0091-6749

Vignola, A.M; Chiappara, G; Gagliardo, R; Gjomarkaj, M; Merendino, A; Siena, L; Bousquet J \& Bonsignore G. (2000). Apoptosis and airway inflammation in asthma. Apoptosis 5, 473-85; ISSN 1360-8185

Wegmann M. (2008). Animal models of chronic experimental asthma - strategies for the identification of new therapeutic targets. Journal of Occupational Medicine and Toxicology 3, S4; ISSN 1745-6673

Wills-Karp, M; Luyimbazi, J; Xu, X; Schofield, B; Neben, T.Y; Karp, C.L \& Donaldson D.D. (1998). Interleukin-13: central mediator of allergic asthma. Science 282:2258-61; ISSN 0036-8075

Wills-Karp, M. (1999). Immunologic basis of antigen-induced airway hyperresponsiveness. Annual Review in Immunology 17, 255-281; ISSN 1545-3278

Wills-Karp, M; Santeliz, J \& Karp, C. L. (2001). The germless theory of allergic disease: revisiting the hygiene hypothesis. Nature Reviews Immunology 1, 69-75; ISSN 14741733

Woolley, K.L; Gibson, P.G; Carty, K; Wilson, A.J; Twaddell, S.H \& Woolley, M.J. (1996). Eosinophil apoptosis and the resolution of airway inflammation in asthma. 
American Journal of Respiratory and Critical Care Medicine 154, 237-243; ISSN 10441549

Yamashita, M; Onodera, A \& Nakayama T. (2007). Immune mechanism of allergic airway disease: regulation by transcriptions factors. Critical Reviews in Immunology 26. 539546; ISSN 1040-8401

Zheng, S.G; Wang, J.H; Stohl, W; Kim, K.S; Gray, J.D \& Horwitz, D.A. (2006). TGF-beta requires CTLA-4 early after T cell activation to induce FoxP3 and generate adaptive CD4+CD25+ regulatory cells. The Journal of Immunology 176, 3321-3329; ISSN 00221767 


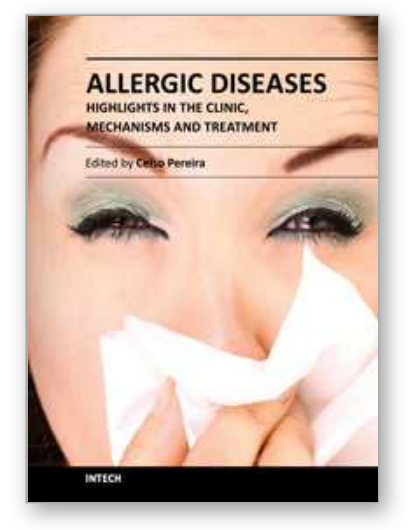

\author{
Allergic Diseases - Highlights in the Clinic, Mechanisms and \\ Treatment \\ Edited by Prof. Celso Pereira
}

ISBN 978-953-51-0227-4

Hard cover, 554 pages

Publisher InTech

Published online 14, March, 2012

Published in print edition March, 2012

The present Edition "Allergic diseases - highlights in the clinic, mechanisms and treatment" aims to present some recent aspects related to one of the most prevalent daily clinical expression disease. The effort of a group of outstanding experts from many countries reflects a set of scientific studies very promising for a better clinical care and also to the treatment and control of the allergy. This book provides a valuable reference text in several topics of the clinical allergy and basic issues related to the immune system response. The inflammatory reaction understanding in allergic disease is clearly evidenced, as well as new strategies for further researches.

\title{
How to reference
}

In order to correctly reference this scholarly work, feel free to copy and paste the following:

Gabriel Morán, Claudio Henriquez and Hugo Folch (2012). Allergic Airway Inflammation, Allergic Diseases Highlights in the Clinic, Mechanisms and Treatment, Prof. Celso Pereira (Ed.), ISBN: 978-953-51-0227-4, InTech, Available from: http://www.intechopen.com/books/allergic-diseases-highlights-in-the-clinicmechanisms-and-treatment/allergic-airway-inflammation

\section{INTECH}

open science | open minds

\section{InTech Europe}

University Campus STeP Ri

Slavka Krautzeka 83/A

51000 Rijeka, Croatia

Phone: +385 (51) 770447

Fax: +385 (51) 686166

www.intechopen.com

\section{InTech China}

Unit 405, Office Block, Hotel Equatorial Shanghai

No.65, Yan An Road (West), Shanghai, 200040, China 中国上海市延安西路65号上海国际贵都大饭店办公楼 405 单元

Phone: +86-21-62489820

Fax: $+86-21-62489821$ 
(C) 2012 The Author(s). Licensee IntechOpen. This is an open access article distributed under the terms of the Creative Commons Attribution 3.0 License, which permits unrestricted use, distribution, and reproduction in any medium, provided the original work is properly cited. 